\title{
Pengenalan Computational Thinking untuk Meningkatkan Kemampuan Problem Solving
}

\author{
Lisnawita*1, Taslim², Musfawati $^{3}$ \\ 1,2Program Studi Teknik Informatika Fakultas Ilmu Komputer, Universitas Lancang Kuning \\ ${ }^{3}$ Program Studi Sistem Informasi, Fakultas Ilmu Komputer, Universitas Lancang Kuning \\ *e-mail: lisnawita@unilak.ac.id¹, taslim@unilak.ac.id², musfawati@unilak.ac.id³
}

\begin{abstract}
The Faculty of Agriculture, Lancang Kuning University, is one of the faculties of the Raja ali Hajj foundation which was founded in 1982. The development of increasingly sophisticated technology, encourages every faculty to be able to keep abreast of the times. although engaged in agriculture, then students as the next generation must be able to compete in this digital economy era and of course they must also be able to adjust the current technological developments because if it cannot be adapted to today, it is very likely that the students themselves will be left behind, both in terms of the use of technology to computational thinking. At this time the ability of students to solve problems is still low, this dedication is done by lecturing and giving examples of cases with resolution. This training can open the mindset of students and help students become accustomed to thinking logically, structured and creative. And students can focus on the ability to think to find solutions to problems and find other alternatives so that they get the best solution. The results of the training conducted can increase student understanding by $84.7 \%$. Seen from the participants who were able to solve some examples of cases that were given well
\end{abstract}

Keywords : Computational Thinking, Problem Solving, Ability

\begin{abstract}
Abstrak
Fakultas ilmu pertanian Universitas Lancang Kuning adalah salah satu fakultas milik yayasan Raja ali haji yang didirikan pada tahun 1982. Perkembangan teknologi yang semakin canggih ini, mendorong setiap fakultas harus bisa mengikuti perkembangan zaman. meskipun bergerak dibidang pertanian, maka mahasiswa sebagai generasi penerus harus mampu berdaya saing di era ekonomi digital ini dan tentunya juga harus bisa menyesuaikan perkembangan teknologi saat ini, karena jika tidak bisa beradaftasi dengan zaman sekarang, kemungkinan besar mahasiswa itu sendiri akan bisa ketertinggalan, baik dari segi penggunaan teknologi hingga berpikir secara komputasional. Pada saat ini kemampuan mahasiswa dalam menyelesaikan masalah masih rendah, Terlihat dari caranya menyelesaikan suatu permasalahan yang belum memberikan solusi yang baik. Pada pengabdian ini dilakukan dengan ceramah dan memberikan contoh kasus dengan penyelesaiannya. Pelatihan ini dapat membuka pola pikir mahasiswa dan membantu mahasiswa agar terbiasa berfikir secara logis, terstruktur dan kreatif. Serta mahasiswa bisa fokus pada kemampuan berpikir untuk mencari pemecahan masalah dan mencari alternative lain sehingga mendapatkan solusi terbaik. Hasil dari Pelatihan yang dilakukan dapat meningkatkan pemahaman mahasiswa sebesar 84,73\%. Terlihat dari peserta yang mampu menyelesaikan beberapa contoh kasus yang diberikan dengan baik.
\end{abstract}

Kata Kunci : berpikir secara komputasional, pemecahan masalah, kemampuan

\section{PENDAHULUAN}

Fakultas ilmu pertanian Universitas Lancang Kuning adalah salah satu fakultas milik yayasan Raja ali haji yang didirikan pada tahun 1982. Fakultas ini Memiliki dua Prodi yaitu: Prodi Agroteknologi dan Prodi Agribisnis. Tentunya dengan lamanya berdiri fakultas tersebut sehingga menghasilkan alumni yang sangat banyak tersebar di berbagai provinsi dengan yang bekerja sesuai dengan keahlian nya.

Dengan perkembangan teknologi yang semakin canggih ini, meskipun fakultas ini bergerak dibidang pertanian, dimana mahasiswa beraktifitas seperti menanam bibit, membuat kompos dan lain sebagainya. Sebagai generasi penerus maka mahasiswa dituntut harus mampu 
berdaya saing di era ekonomi digital ini dan tentunya juga harus bisa menyesuaikan perkembangan teknologi saat ini, karena jika tidak bisa beradaftasi dengan zaman sekarang, kemungkinan besar mahasiswa itu sendiri akan bisa ketertinggalan, baik dari segi Penggunaan Teknologi hingga berpikir secara komputasional, termasuk berpikir komputasional dalam menanam bibit ataupun membuat kompos dan lain sebagainya, mahasiswa harus mampu menyesuaikan dengan perkembangan teknologi sehingga dalam kegiatan yang dilakukan mahasiswa mendapatkan hasil yang lebih baik.

Pengabdian ini pernah dilakukan oleh (Syarifuddin et al., 2016) Permainan GORLIDS terbukti dapat memunculkan sifat berpikir computational thinking anak, (Munir, 2018),(Titien S. Sukamto, Ayu Pertiwi, Affandy, Abdul Syukur, Nisa'ul Hafdhoh, 2019), (Muhammad Syarifuddin, Diva Fardiana Risa, Azifatul Istna Hanifah, 2019) Guru memahami Computational Thinking, dan memiliki strategis yang nyata dalam penerapan Computational Thinking dikelasnya,(Mastura Diana Marieska, Dian Paupi Rini, Nabila Rizky Oktadini, Novi Yusliani, 2019), peserta dari mitra termotivasi untuk menyelesaikan soal-soal yang memerlukan kemampuan berpikir secara komputasional,(Hidayat \& Pertiwi, 2020), Bertambahnya pengetahuan/wawasan, networking, dan peluang/kesempatan untuk memperoleh prestasi siswa pada Bebras Challenge 2020, (Dewi Pramudi Ismi, Murinto \& Universitas, 2020),(Rosyda, Azhari, Dahlan, Jl, \& Selatan, 2020), dapat diimplementasi dalam proses belajar di sekolah yang akan membantu siswa untuk lebih berpikir secara komputatif (Wibawa, Saputra, Sasongko, \& Adhy, 2020), Penerapan metode CT pada penyelesaian persoalan didapatkan bahwa hasil yang diperoleh lebih optimal (Suktiningsih, Supatmiwati, Gusti, \& Dasriani, 2021)

\section{METODE}

Kegiatan Pengabdian Masyarakat ini dilakukan dengan 3 tahapan

Tahap Pertama menyebarkan kuesioner (Pre Test) kepada mitra pengabdian yang bertujuan untuk mengetahui pemahaman mitra terhadap materi yang di akan sampaikan

Tahap Kedua yaitu Memberikan Penyuluhan, diaman setiap peserta itu diberikan pengarahan terlebih dahulu mengenai materi yang disampaiakan seperti: apa itu Commputational Thinking(CT), Metode yang digunakan dalam Commputational Thinking(CT), Manfaat Commputational Thinking(CT), Contoh Commputational Thinking(CT) Pada tahapan ini metode yang diguankan adalah Diskusi dan Ceramah

Tahap Terakhir yaitu fase evaluasi, evaluasi yang dilakukan pada kegiatan ini meliputi :

1. Evaluasi proses, ini dilakukan ketika pelatihan yang diberikan sedang berlangsung, sehingga apa saja aktivitas yang dilakukan, baik Tanya jawab dari peserta akan dinilai, tentunya ini berkaitan dengan tingkat pemahaman peserta dalam menagkap materi yang sudah disampaiakn oleh pemateri dalam kegiatan ini

2. Evaluasi hasil, ini dilakukan dengan memberikan peserta satu kasus permasalahan, kemudian meminta peserta aktif dalam menyelesaikan permasalahan tersebut dengan mempraktekkan materi yang sudah diberikan tersebut, sehingga peserta mampu berpikir secara komputasional sehingga mendapatkan solusi terbaik terhadap permasalahan tersebut

3. Evaluasi Akhir, Peserta diberikan kuesioner (Post Test) untuk diisi sebagai evaluasi tim pengabdi dalam mengukur tingkat keberhasailan dari pelatihan yang telah dilakukan

\section{HASIL DAN PEMBAHASAN}

Kegiatan pengabdian ini dilaksanakan dengan sistem daring, dihadiri oleh peserta 10 orang peserta. Setiap peserta diberikan Modul tentang Computational Thinking. Sebum memulai 
kegiatan pelatihan ini, peserta diminta untuk mengisi kuesioner atau Pre test, sehingga dapat diketahui pengetahuan dasar peserta sebelum pelatihan dilakukan. Setelah itu kegiatan dibuka dan pemateri menjelaskan materi dasar, seperti pengertian Computational thinking. Mengapa Penting untuk berpikir secara komputasi, Metode yang digunakan pada Computational thinkin, dan bagaimana cara mengimplementasikan Computational thinking pada kehidupan sehari-hari. Sehingga diberikan penjelasn tentang sebuah kasus. Setelah Materi di sampaikan kepada peserta, kemudian dilakukan tanya jawab sehingga peserta memahami apa yang sudah disampaikan pemateri, setelah itu peserta diminta mengerjakan latihan soal untuk mengukur seberapa paham peserta dengan apa yang sudah diberikan oleh pemateri. Di akhir kegiatan pemateri meminta peserta untuk mengisi kuesioner Post Test sehingga dapat mengukur tingkat keberhasilan dari kegiatan pelatihan yang telah dilakukan. Untuk mengukur kuesioner ini menggunakan skala Guttman. Skala Guttman adalah skala yang membutuhkan jawaban tegas, seperti positif - negative, ya - tidak, pernah - tidak pernah, tinggi - rendah, baik - buruk dan seterusnya. Pada skala Guttman, hanya ada dua interval, Yaitu Setuju dan tidak setuju. Skala Guttman dapat dibuat dalam bentuk pilihan daftar checklist maupun ganda.

Pada Pengabdian ini diikuti oleh Responden sebanyak 10 orang, Berikut hasil perhitungan dengan menggunakan skala Guttman pada tabel 1.

Tabel 1. Total Jawaban Responden Pre - Test

\begin{tabular}{clcccccccccc}
\hline No & \multicolumn{1}{c}{ Responden } & P1 & P2 & P3 & P4 & P5 & P6 & P7 & P8 & P9 & P10 \\
\hline 1 & Rostauli Silalahi & 0 & 0 & 0 & 0 & 0 & 0 & 0 & 0 & 0 & 0 \\
2 & Erika Lumban Gaol & 0 & 0 & 0 & 0 & 0 & 0 & 0 & 0 & 0 & 0 \\
3 & Meila Putri & 0 & 0 & 0 & 0 & 0 & 0 & 0 & 0 & 0 & 0 \\
4 & Alma Oktarindra & 0 & 0 & 0 & 0 & 0 & 0 & 0 & 0 & 0 & 0 \\
5 & Lamtiurma & 1 & 1 & 0 & 1 & 0 & 0 & 0 & 0 & 0 & 0 \\
6 & Jhosua marsella & 0 & 0 & 0 & 0 & 0 & 0 & 0 & 0 & 0 & 0 \\
7 & Astrie Vita maisari & 0 & 0 & 0 & 0 & 0 & 0 & 0 & 0 & 0 & 0 \\
8 & Rio Sinaga & 0 & 0 & 0 & 0 & 0 & 0 & 0 & 1 & 0 & 0 \\
9 & Harry m.p Siadari & 0 & 0 & 0 & 0 & 0 & 0 & 1 & 1 & 0 & 0 \\
10 & Marisi Enjelina Panjaitan & 0 & 0 & 0 & 0 & 0 & 0 & 0 & 0 & 0 & 0 \\
11 & Sindy Friska Yonnari & 0 & 0 & 0 & 0 & 0 & 0 & 0 & 0 & 0 & 0 \\
12 & Sutomo & 0 & 0 & 0 & 0 & 0 & 0 & 0 & 0 & 0 & 0 \\
13 & Riyanti Rahayu & 0 & 0 & 0 & 0 & 0 & 0 & 0 & 0 & 0 & 0 \\
\hline
\end{tabular}

Keterangan: P1-P12 adalah pertanyaan pertama, hingga P11 adalah pertanyaan kesebelas

Tabel 2. Persentase Pengetahuan Responden Pre -Test

\begin{tabular}{ccc}
\hline Item Pertanyaan & $\begin{array}{c}\text { (\%) Jawaban } \\
\text { ya }\end{array}$ & $\begin{array}{c}\text { (\%) Jawaban } \\
\text { ya }\end{array}$ \\
\hline P1 & 1 & 16,66 \\
P2 & 1 & 16,66 \\
P3 & 0 & 0,00 \\
P4 & 1 & 0,00 \\
P5 & 0 & 0,00 \\
P6 & 0 & 0,00 \\
P7 & 1 & 16,66 \\
P8 & 2 & 33,34 \\
P9 & 0 & 0,00 \\
P10 & 0 & 0,00 \\
Total & 6 & 100,00 \\
Rata-Rata & 0,6 & 10 \\
\hline
\end{tabular}


Perhitungan Jawaban "ya" dari angket yaitu Jawaban "ya" rata-rata $\quad: 0,6 / 10 \times 100=6 \%$

Tabel 3. Total Jawaban Responden Post Test

\begin{tabular}{clcccccccccc}
\hline No & \multicolumn{1}{c}{ Responden } & P1 & P2 & P3 & P4 & P5 & P6 & P7 & P8 & P9 & P10 \\
\hline 1 & Rostauli Silalahi & 1 & 1 & 1 & 1 & 1 & 1 & 1 & 1 & 1 & 0 \\
2 & Erika Lumban Gaol & 1 & 1 & 1 & 1 & 1 & 1 & 1 & 1 & 0 & 1 \\
3 & Meila Putri & 1 & 1 & 1 & 1 & 1 & 1 & 1 & 1 & 1 & 1 \\
4 & Alma Oktarindra & 1 & 1 & 1 & 1 & 1 & 1 & 1 & 1 & 1 & 1 \\
5 & Lamtiurma & 1 & 1 & 1 & 1 & 1 & 1 & 1 & 1 & 1 & 1 \\
6 & Jhosua marsella & 1 & 1 & 1 & 1 & 1 & 1 & 1 & 0 & 1 & 0 \\
7 & Astrie Vita maisari & 1 & 1 & 1 & 1 & 1 & 1 & 1 & 1 & 1 & 1 \\
8 & Rio Sinaga & 1 & 1 & 1 & 1 & 1 & 1 & 1 & 1 & 1 & 1 \\
9 & Harry m.p Siadari & 1 & 1 & 1 & 1 & 1 & 1 & 0 & 1 & 1 & 1 \\
10 & Marisi Enjelina Panjaitan & 1 & 1 & 1 & 1 & 1 & 1 & 1 & 0 & 0 & 0 \\
11 & Sindy Friska Yonnari & 1 & 1 & 1 & 1 & 1 & 0 & 0 & 0 & 1 & 0 \\
12 & Sutomo & 1 & 1 & 1 & 1 & 1 & 1 & 1 & 1 & 1 & 1 \\
13 & Riyanti Rahayu & 1 & 1 & 1 & 1 & 1 & 1 & 1 & 1 & 1 & 1 \\
\hline
\end{tabular}

Tabel 4. Persentase Pengetahuan Responden Post Test

\begin{tabular}{ccc}
\hline Item Pertanyaan & $\begin{array}{c}\text { (\%) Jawaban } \\
\text { ya }\end{array}$ & $\begin{array}{c}\text { (\%) Jawaban } \\
\text { ya }\end{array}$ \\
\hline P1 & 13 & 11,01 \\
P2 & 13 & 11,01 \\
P3 & 13 & 11,01 \\
P4 & 13 & 11,01 \\
P5 & 13 & 11,01 \\
P6 & 12 & 10,16 \\
P7 & 11 & 9,32 \\
P8 & 10 & 8,47 \\
P9 & 11 & 9,32 \\
P10 & 9 & 7,62 \\
Total & 118 & 100 \\
Rata-Rata & 9,07 & 90,7 \\
\hline
\end{tabular}

Perhitungan Jawaban "ya" dari angket: Jawaban "ya” rata-rata : 9,07/10 x 100\% = 90,7 \%, Jadi Pengetahuan 90,7 - $6=84,7 \%$

\section{KESIMPULAN}

Pelaksanaan kegiatan Pengabdian Kepada Masyarakata ini disambut antusias oleh peserta, sehingga mampu meningkatkan pengetahuan dan kemampuan peserta dalam memahami Computational Thinking sebesar 84,7\%. Selaian itu Peserta Juga mampu meneyelesaikan sebuah kasus dengan menerapkan metode Computainal Thinking

\section{UCAPAN TERIMA KASIH}

Penulis mengucapkan terima kasih kepada Fakultas Ilmu Komputer Universitas Lancang Kuning yang telah memberi dukungan financial terhadap kegiatan pengabdian ini. 


\section{DAFTAR PUSTAKA}

Dewi Pramudi Ismi, Murinto, D. N., \& Universitas. (2020). Pelatihan computational thinking bagi guru dan siswa SMA/SMK/MA Muhammadiyah di Wilayah Kota Yogyakarta. Seminar Nasional Hasil Pengabdian Kepada Masyarakat, (November), 379-388.

Hidayat, E. Y., \& Pertiwi, A. (2020). Pembelajaran Computational Thinking untuk Siswa SMA Institut Indonesia Semarang. Abdimasku, 3(3), 93-98.

Mastura Diana Marieska, Dian Paupi Rini, Nabila Rizky Oktadini, Novi Yusliani, Y. (2019). Sosialisasi dan Pelatihan Computational Thinking. Prosiding Annual Research Seminar 2019, 5(2), 7-10.

Muhammad Syarifuddin, Diva Fardiana Risa, Azifatul Istna Hanifah, N. (2019). Experiment Computational Thinking: Upaya Meningkatkan Kualitas Problem Solving Anak Melalui Permainan Gorlids. Jurnal Mitra Pendidikan, 3(6), 807-822.

Munir, M. A. (2018). Strategi Pendidikan Islam Dalam Menghadapi Globalisasi Ilmu Pengetahuan Dan Teknologi Muchamad Agus Munir 目. El-HiKMAH, 12(2), 122-139.

Rosyda, M., Azhari, A., Dahlan, U. A., Jl, K., \& Selatan, R. (2020). Pelatihan computational thinking dan pembuatan game sederhana bagi guru SD Muhammadiyah se-Kecamatan Wirobrajan. Seminar Nasional Hasil Pengabdian Kepada Masyarakat, (November), 339-348.

Suktiningsih, W., Supatmiwati, D., Gusti, N., \& Dasriani, A. (2021). Pengenalan Pemikiran Computational Thinking untuk Guru MI dan MTs Pesantren Nurul Islam Sekarbela. Jurnal Karya Untuk Masyarakat, 2(1), 91-102.

Syarifuddin, M., Risa, D. F., Hanifah, A. I., Informasi, P. T., Komputer, I., Brawijaya, U., ... Brawijaya, U. (2016). GORLIDS ( Algorithm for Life Kids ): Upaya Meningkatkan Pola Computational Thinking Anak usia 4-6 Tahun secara Problem Solving, Terstruktur, Kritis dan Logis. 1-15.

Titien S. Sukamto, Ayu Pertiwi, Affandy, Abdul Syukur, Nisa'ul Hafdhoh, E. Y. H. (2019). Pengenalan Computational Thinking Sebagai Metode Problem Solving Kepada Guru dan Siswa Sekolah di Kota Semarang. ABDIMASKU, 2(2), 99-107.

Wibawa, H. A., Saputra, R., Sasongko, P. S., \& Adhy, S. (2020). Pelatihan Computational Thinking bagi Guru SMP-SMK Muhammadiyah 2 Kota Semarang Helmie. E-DIMAS, 11(2), 173-178. 